Отримано: 19 травня 2018 р.

Прорецензовано: 26 травня 2018 р.

Прийнято до друку: 01 червня 2018 р. e-mail: khoma_iso@tvnet.if.ua

DOI: $10.25264 / 2311-5149-2018-9(37)-185-190$
Хома С. В., Костюк У. З. Практичні аспекти обліку й оцінки оренди в орендаря згідно з МСФ3 (IFRS) 16 «Оренда». Наукові записки Наиіонального університету «Острозька академія». Серія «Економіка» : науковий журнал. Острог : Вид-во НаУОА, червень 2018. № 9(37). С. 185-190.

Хома Світлана Василівна,

кандидат економічних наук, дочент, доцент кафедри обліку і аудиту

Івано-Франківського національного технічного університету нафти і газу

Костюк Уляна Зіновї̈вна,

кандидат економічних наук, доиент, доиент кафедри обліку і аудиту

Івано-Франківського національного технічного університету нафти і газу

\title{
ПРАКТИЧНІ АСПЕКТИ ОБЛІКУ Й ОЦІНКИ ОРЕНДИ В ОРЕНДАРЯ ЗГІДНО 3 МСФЗ (IFRS) 16 «ОРЕНДА»
}

У статті розглянуто основні положення міжнародного стандарту фінансової звітності (IFRS) 16 «Оренда». Визначено нові підходи до відображення в обліку орендаря орендних операцій за єдиною моделлю обліку оренди. Згідно з иією моделлю будь-яку оренду як операчійну, так $і$ фінансову, слід визнавати як в активах, так $i$ в зобов'язаннях балансу орендаря.

Ключові слова: оренда, орендар, операчійна оренда, фінансова оренда.

\section{Хома Светлана Васильевна,}

кандидат экономических наук, доцент, доцент кафедры учета и аудита Ивано-Франковского национального технического университета нефти и газа

Костюк Ульяна Зиновьевна, кандидат экономических наук, дочент, доиент кафедры учета и аудита

Ивано-Франковского национального технического университета нефти и газа

\section{ПРАКТИЧЕСКИЕ АСПЕКТЫ УЧЕТА И ОЦЕНКИ АРЕНДЫ В АРЕНДАТОРА В СООТВЕТСТВИИ С МСФО (IFRS) 16 «АРЕНДА»}

В статье рассмотрены основные положения международного стандарта финансовой отчетности (IFRS) 16 «Аренда». Определены новые подходы к отражению в учете арендатора арендных операчий по единой модели учета аренды. Согласно этой модели любая аренда, как операционная, так и финансовая, должна признаваться как 8 активах, так и в обязательствах баланса арендатора.

Ключевые слова: аренда, арендатор, операчионная аренда, финансовая аренда.

\section{Svitlana Khoma,}

Ph.D. in Economics, Associate Professor, Department of Accounting and Audit, Ivano-Frankivsk National Technical University of Oil and Gas

\section{Ulyana Kostyuk,}

Ph.D. in Economics, Associate Professor, Department of Accounting and Audit, Ivano-Frankivsk National Technical University of Oil and Gas

\section{PRACTICAL ASPECTS OF ACCOUNTING AND EVALUATING LEASE IN THE LESSEE ACCORDING TO IFRS 16 «LEASE»}

International Financial Reporting Standard (IFRS) 16 «Leases» main provisions were considered in the article. New approaches to lessee's lease agreement accounting by means of a single accounting model were considered. According to this model, any lease, operating and financial, should be recognized both in assets and in the obligations of the lessee's balance sheet.

Key words: leases, lessee, operating leases, finance leases.

Постановка проблеми. 31 січня 2019 року вступає в силу МСФЗ (IFRS) 16 «Оренда» та замінить МСБО (IAS) 17 «Оренда». Метою МСФЗ (IFRS) 16 «Оренда» є вирішення питань користувачів фінансової звітності щодо ії обмеженої порівнянності, що виникає через різниці в методах обліку операційної і фінансової оренди відповідно до вимог нині чинного МСБО (IAS) 17 «Оренда», а також обмеженості 
представленої інформації про операційну оренду і схильності організацій до ризиків, пов'язаних із договорами оренди.

Аналіз останніх досліджень і публікацій. Для врегулювання даних питань рада 3 MCФ3 (IASB) спільно з американським національним розробником стандартів - Радою з стандартів фінансового обліку CША (FASB) прийняли рішення про розробку нового підходу до порядку обліку оренди з боку орендаря, згідно з яким орендар визнає активи та зобов'язання щодо прав і обов'язків, що виникають із договорів оренди (з обмеженим числом винятків), а також про розширення вимог до розкриття інформації про оренду. Початкова мета проекту полягала у розробці конвергованого стандарту з МСФЗ і ЗПБО США. У 2009 році був опублікований дискусійний документ, а у 2010, 2013 роках вийшли проміжні версії стандартів від IASB та FASB. Результати такої співпраці знайшли місце в обговореннях серед науковців [1, $2,3]$.

Однак Рада з МСФЗ і Рада зі стандартів фінансового обліку США прийшли до різних висновків із ряду питань, враховуючи визнання та подання витрат орендарями. У зв’язку з цим Проект стандарту 3 оренди ED/2013/6 «Оренда», опублікований у 2013 році, відрізняється від МСФЗ (IFRS) 16 в ряді аспектів.

Метою статті є розкриття основних положень MCФ3 (IFRS) 16 «Оренда» та визначення подальшого порядку обліку орендних операцій орендаря.

Виклад основного матеріалу. Облік орендних операцій, особливо з боку орендаря, піддався критиці під час глобальної фінансової кризи через те, що порядок визнання контрактних зобов'язань за договорами оренди був непрозорим і незручним для користувачів звітності. За повідомленням Ради 3 МСФ3 у компаній, що застосовують МСФ3, із 3,3 трильйонів доларів зобов'язань з оренди понад 85\% таких коштів не відображаються в балансі [4]. Це пов'язано з тим, що більшість договорів оренди на сьогодні класифікують як операційну оренду, й інформацію про них відображають тільки у примітках до фінансової звітності. Виключення орендних активів і зобов'язань із балансу дає інвесторам і фінансовим аналітикам неповну інформацію про фінансову позицію компаній-орендарів.

Новий стандарт 3 обліку оренди MCФ3 (IFRS) 16 «Оренда», що був опублікований Радою 3 міжнародних стандартів у січні 2016 року, для всіх договорів оренди вводить вимогу про єдину модель обліку оренди. Згідно з цією моделлю будь-яка оренда як операційна, так і фінансова, має визнаватись як в активах, так і в зобов'язаннях балансу орендаря.

\section{Звільнення від визнання}

Орендар має право прийняти рішення про незастосування моделі обліку оренди, якщо:

(а) оренда - короткострокова (до 12 місяців);

(б) базовий актив оренди має низьку вартість.

У документі «Основи для висновків», що супроводжує такий стандарт, указано, що йдеться про активи, вартість яких, коли вони нові, не перевищує 5000 доларів США.

Якщо орендар приймає рішення не застосовувати модель обліку оренди відповідно до вимог пунктів 22-49 МСФ3 (IFRS) 16 «Оренда» щодо короткострокової оренди або оренди, у якій базовий актив має низьку вартість, орендар має визнавати орендні платежі як витрати:

- або лінійним методом протягом терміну оренди;

- або з використанням іншого систематичного підходу,

що є аналогічно порядку відображення нині діючої моделі операційної оренди.

\section{Визначення оренди}

MCФ3 (IFRS) 16 «Оренда» проводить розмежування між договором оренди і договором на надання послуг на основі того, чи може компанія контролювати орендований актив.

Договір загалом або окремі його компоненти є договором оренди, якщо він:

- надає клієнту право контролювати використання;

- ідентифікованого активу;

- протягом певного періоду часу за винагороду.

Контроль перейшов до клієнта, якщо клієнт:

- має право отримувати практично всі економічні вигоди від використання ідентифікованого активу; і

- має право керувати використанням даного активу.

Компанія має оцінити, чи є договір загалом або його окремі елементи договором оренди на момент укладення договору та у випадку змін умов і термінів оренди.

Визначення грунтується на понятті контролю, оскільки Рада з МСФЗ вирішила, що для здійснення контролю над активом клієнт має не тільки мати право на отримання практично всіх економічних вигод від його експлуатації протягом періоду використання (елемент «вигоди»), але також здатність керувати використанням даного активу (елемент «повноваження»). Зазначена вимога відповідає концепції контролю в МСФ3 (IFRS) 10 «Консолідована фінансова звітність» і МСФ3 (IFRS) 15 «Виручка за договорами з клієнтами». У Стандарті наведено докладні вказівки для визначення того, чи були дотримані такі 
умови. Передбачається, що в деяких випадках буде потрібно застосувати судження під час проведення оцінювання.

\section{Визнання орендної угоди в орендаря}

Головна зміна в порядку обліку полягає у вимозі до орендарів відображати активи і зобов'язання, пов'язані з договорами оренди, у звіті про фінансовий стан. Згідно з MCФ3 (IFRS) 16 «Оренда» будь-яку оренду для орендаря розглядають як операцію фінансування.

Орендар застосовує єдину модель обліку оренди, відповідно до якої на дату початку оренди він визнає:

АКТИВ : «Право Користування» - ПАСИВ : «Зобов'язання з Оренди».

Очінка орендної угоди в орендаря

На дату початку оренди орендар має оцінювати актив у формі Права користування за первісною вартістю. Первісна вартість активу у формі Права користування має містити величину первісної оцінки зобов'язання з оренди.

На дату початку оренди орендар оцінює зобов'язання з оренди за дисконтованою вартістю орендних платежів, які ще не здійснені на цю дату.

Орендні платежі необхідно дисконтувати з використанням процентної ставки, передбаченої в договоpi оренди. Така ставка в багатьох випадках може бути аналогічна ставці залучення додаткових позикових коштів орендарем. Це пов'язано з тим, що обидві ставки враховують кредитне становище орендаря, термін оренди, характер і якість наданого забезпечення і економічне середовище, у якому здійснюється операція.

Приклад 1. 1 січня 2019 року Орендар укладає договір оренди автомобіля на 3 роки. Щорічний орендний платіж становить 3000 в.о. (валютні одиниці) та містить 600 в. о. плати орендодавцю за технічне обслуговування автомобіля. Орендні платежі мають сплачуватися в кінці року.

Орендарю невідомо, яку відсоткову ставку використовував орендодавець під час розрахунку суми орендної плати, тому під час обчислення теперішньої (дисконтованої) вартості мінімальних орендних платежів орендар буде застосовувати відсоткову ставку додаткових позик орендаря $-6,87 \%$.

Це така ставка відсотка, яку мав би сплачувати орендар за подібну оренду, або (якщо ії неможливо визначити) ставка, яку на початку терміну оренди сплачував би орендар у разі запозичення коштів, необхідних для придбання активу, на подібний термін та за подібною гарантією.

На дату початку оренди 1 січня 2019 року орендар оцінює теперішню вартість трьох орендних платежів у розмірі 2400 в. о. (за вирахуванням вартості щорічного технічного обслуговування на суму 600 в. о., оскільки супутні витрати, що підлягають відшкодуванню орендодавцю, не враховуються при розрахунку), сплачених у кінці року, за ставкою 6,87\% річних (коефіцієнт ануїтету - 2,63056), що становить $-2400 \times 2,63056=6313$ в.о.

Отже, 01.01.2019 р. орендар визнає активи та зобов'язання так:

Дт «Право користування» -6313

Кт «Зобов'язання з оренди» - 6313

\section{Наступна оцінка активу у формі Права користування}

Після первісного визнання орендар проводить оцінку активу у формі Права користування, застосовуючи модель обліку за собівартістю або модель переоцінки згідно з МСБО (IAS) 16 «Основні засоби» (таким чином, орендар визнає амортизацію та накопичені збитки від знецінення у Звіті про прибутки і збитки, а переоцінку - в іншому сукупному доході, якщо застосовують відповідну модель). Водночас, якщо орендар застосовує модель справедливої вартості згідно з МСБО (IAS) 40 «Інвестиційна нерухомість» щодо інвестиційної нерухомості, орендар також має застосовувати дану модель справедливої вартості щодо активів в формі Права користування, які задовольняють визначенню інвестиційної нерухомості в МСБО (IAS) 40.

Під час застосування моделі обліку за первісною вартістю за вирахуванням накопиченої амортизації орендар має амортизувати актив у формі Права користування з дати початку оренди до більш ранньої 3 наступних дат: дата закінчення терміну корисного використання активу у формі Права користування або дата закінчення терміну оренди.

За умовами Прикладу 1 сума щорічних амортизаційних відрахувань складатиме -6313 в. о. $\div 3$ роки $=2104$ (в.о.)

\section{Наступна оиінка Зобов'язання з оренди}

Після дати початку оренди орендар повинен оцінювати Зобов'язання з оренди шляхом:

(а) збільшення балансової вартості на суму амортизації дисконту на зобов'язання з оренди;

(б) зменшення балансової вартості на суму сплачених орендних платежів за умовою угоди;

(в) переоцінки або модифікації договорів оренди.

Розподіл дисконту на зобов'язання з оренди між звітними періодами протягом строку оренди здійснюється із застосуванням орендної ставки відсотка на залишок зобов'язань на початок звітного періоду.

За умовами прикладу 1 розподіл фінансових витрат представлено в таблиці 1. 
Амортизація дисконту за Зобов'язаннями з оренди

\begin{tabular}{|c|c|c|c|c|c|}
\hline Дата & $\begin{array}{c}\text { Річні орендні } \\
\text { платежі до } \\
\text { сплати } \\
\text { в кінці року }\end{array}$ & $\begin{array}{c}\text { Відшкодування } \\
\text { витрат на тех- } \\
\text { нічне обслугову- } \\
\text { вання }\end{array}$ & $\begin{array}{c}\text { Відсотки (6,87\%), на- } \\
\text { раховані на залишок } \\
\text { зобов'язання } \\
\text { (к.6 х 6,87\%) }\end{array}$ & $\begin{array}{c}\text { Зменшення } \\
\text { зобов'язання 3 } \\
\text { оренди } \\
\text { (к.2- к.3- к. 4) }\end{array}$ & $\begin{array}{c}\text { Залишок } \\
\text { зобов'язання з } \\
\text { оренди на кінець } \\
\text { року (к.6-к.5) }\end{array}$ \\
\hline $\mathbf{1}$ & $\mathbf{2}$ & $\mathbf{3}$ & $\mathbf{4}$ & $\mathbf{5}$ & $\mathbf{6}$ \\
\hline 31.12 .19 & 3000 & 600 & 434 & 1966 & $\mathbf{6 3 1 3}$ \\
\hline 31.12 .20 & 3000 & 600 & 299 & 2101 & 4347 \\
\hline 31.12 .21 & 3000 & 600 & 154 & 2246 & 246 \\
\hline Разом & $\mathbf{9 0 0 0}$ & $\mathbf{1 8 0 0}$ & $\mathbf{8 8 7}$ & $\mathbf{6 3 1 3}$ & - \\
\hline
\end{tabular}

31.12.2019 р. орендар здійснить такі записи з визнання витрат:

Нарахування амортизації за перший рік:

Дт «Витрати на амортизацію» - 2104

Кт «Право користування» - 2104

Сплата першого орендного платежу 31.12.19:

Дт «Витрати на технічне обслуговування» -600

Дт «Витрати на відсотки» - $434(6,87 \%$ × 6313$)$

Дт «Зобов’язання з оренди» - 1966

Кт «Грошові кошти»- 3000

Наприкінці першого року оренди (31.12.2019 р.)

- балансова вартість орендаря Права користування автомобіля буде оцінене за первісною вартістю за вирахуванням накопиченої амортизації:

$$
4209 \text { в.о. (6 } 313-2104) \text {, }
$$

- Зобов'язання з оренди буде оцінене шляхом збільшення балансової вартості на суму амортизації дисконту на зобов'язання з оренди і зменшення балансової вартості на суму сплачених орендних платежів:

$$
4347 \text { г.о. }(6313+434-2400) \text {. }
$$

У звіті про прибутку і збитки протягом трьох років оренди буде наведена така інформація (таблиця 2):

Таблиия 2

Вплив на звіт про прибутки і збитки

\begin{tabular}{|c|c|c|c|c|}
\hline Дата & $\mathbf{2 0 1 9}$ & $\mathbf{2 0 2 0}$ & $\mathbf{2 0 2 1}$ & Разом \\
\hline Витрати на амортизацію & 2104 & 2104 & 2105 & $\mathbf{6 3 1 3}$ \\
\hline Фінансові витрати & 434 & 299 & 154 & $\mathbf{8 8 7}$ \\
\hline Витрати на обслуговування & 600 & 600 & 600 & $\mathbf{1 8 0 0}$ \\
\hline Разом & $\mathbf{3 1 3 8}$ & $\mathbf{3 0 0 3}$ & $\mathbf{2 8 5 9}$ & $\mathbf{9 0 0 0}$ \\
\hline
\end{tabular}

Окрім суми первісної оцінки зобов'язання з оренди первісна вартість активу у формі права користування включає:

- орендні платежі орендодавцю, сплачені на дату початку оренди або до неї, за вирахуванням стимулів для укладення договору оренди;

- початкові прямі витрати, понесені орендарем;

- оцінку витрат, які будуть понесені орендарем під час демонтажу і вибуття активу, відновленні ділянки, на якому він був розташований, або відновленні орендованого активу до стану, передбаченого умовами оренди, за винятком випадків, коли такі витрати понесені для виробництва матеріальних запасів.

Приклад 2. 1 січня 2019 року Орендар укладає договір оренди приміщення на 5 років. Орендні платежі становлять 50000 в. о. і підлягають сплаті на початку кожного року. Орендар відшкодовує додаткові витрати, пов'язані з укладенням договору оренди, на суму 15000 в. о. (зокрема, 10000 в. о. - сплата відшкодування колишньому орендареві, 5000 в. о. - сплата агенту нерухомості). Ставка запозичення становить $6 \%$ річних, що відображає фіксовану ставку, за якою він міг би запозичити суму, аналогічну вартості Права користування.

Таким чином, на дату початку оренди 1 січня 2019 року орендар сплачує платіж за оренду першого року в сумі 50000 в. о. і початкові прямі витрати у сумі 15000 в. о., та оцінює зобов'язання за теперішньою вартістю решти чотирьох орендних платежів у розмірі 50000 в. о., сплачених на початку року, дисконтованих за ставкою 6\% річних (коефіцієнт ануїтету - 3,4651), що становить - 50000 х 3,4651 = 173255 в. $о$.

На дату початку оренди 01.01.2019 р. орендар визнає активи та зобов'язання так:

Дт «Право користування» - 238255 (173 225+50 000+15000) 
Кт «Зобов’язання з оренди» - 173255 (первісна оцінка Зобов’язання)

Кт «Грошові кошти» - 50000 (орендний платіж на дату початку оренди)

Кт «Грошові кошти» - 15000 (прямі витрати)

Табличя 3

Розподіл витрат за орендною угодою в орендаря

\begin{tabular}{|c|c|c|c|c|c|c|}
\hline \multirow{2}{*}{ Рік } & \multicolumn{3}{|c|}{ Зобов'язання з оренди } & \multicolumn{3}{c|}{ Право користування } \\
\cline { 2 - 7 } & $\begin{array}{c}\text { Річні орендні } \\
\text { платежі до } \\
\text { сплати на по- } \\
\text { чатку року }\end{array}$ & $\begin{array}{c}\text { Відсотки (6\%), } \\
\text { нараховані на зали- } \\
\text { шок зобов'язання }\end{array}$ & $\begin{array}{c}\text { Залишок } \\
\text { зобов'язання } \\
\text { зоренди на } \\
\text { кінець року }\end{array}$ & $\begin{array}{c}\text { Сальдо на } \\
\text { початок } \\
\text { року }\end{array}$ & $\begin{array}{c}\text { Амортизація } \\
\text { (238 255 : на 5 } \\
\text { років) }\end{array}$ & $\begin{array}{c}\text { Сальдо на } \\
\text { кінець року }\end{array}$ \\
\hline 2019 & 50000 & - & 173255 & 238255 & 47651 & 190604 \\
\hline 2020 & 50000 & 10395 & 133650 & 190604 & 47651 & 142953 \\
\hline 2021 & 50000 & 8020 & 91670 & 142953 & 47651 & 95302 \\
\hline 2022 & 50000 & 5500 & 47170 & 95302 & 47651 & 47651 \\
\hline 2023 & 50000 & 2830 & 0 & 47651 & 47651 & 0 \\
\hline Разом & $\mathbf{2 5 0 0 0 0}$ & $\mathbf{2 6 7 4 5}$ & - & - & $\mathbf{2 3 8 2 5 5}$ & - \\
\hline
\end{tabular}

Унаслідок того, що договори про операційну оренду будуть відображатися в бухгалтерському балансі, у орендаря з'явиться більше активів, але одночасно збільшиться обсяг боргових зобов'язань (таблиця 4). Визнання додаткових активів і зобов'язань, а також зміна порядку подання відобразиться на ключових коефіцієнтах результативності орендаря - наприклад, коефіцієнтах, прив'язаних до активів, і коефіцієнтах, що відображають співвідношення позикового і власного капіталу - i, відповідно, може негативно вплинути на здатність компанії виконувати ті чи інші обмежувальні умови договорів кредитування.

Таблиия 4

Аналіз показників Балансу орендаря

\begin{tabular}{|c|c|c|c|c|c|c|}
\hline Стаття Балансу & $\mathbf{0 1 . 0 1 . 2 0 1 9}$ & $\mathbf{3 1 . 1 2 . 2 0 1 9}$ & $\mathbf{3 1 . 1 2 . 2 0 2 0}$ & $\mathbf{3 1 . 1 2 . 2 0 2 1}$ & $\mathbf{3 1 . 1 2 . 2 0 2 2}$ & $\mathbf{3 1 . 1 2 . 2 0 2 3 1}$ \\
\hline $\begin{array}{c}\text { Актив } \\
\text { Право на Користування }\end{array}$ & 238255 & 190604 & 142953 & 95302 & 47651 & 0 \\
\hline $\begin{array}{c}\text { Зобов'язання } \\
\text { Зобов'язання з оренди }\end{array}$ & 173255 & 173255 & 133650 & 91670 & 47170 & 0 \\
\hline \multicolumn{7}{|c|}{ Діюча угода про операційну оренду } \\
\hline $\begin{array}{c}\text { Актив } \\
\text { Право користування }\end{array}$ & - & - & - & - & - & - \\
\hline $\begin{array}{c}\text { Зобов'язання } \\
\text { Зобов'язання з оренди }\end{array}$ & - & - & - & - & - & - \\
\hline
\end{tabular}

Зміниться також і порядок подання витрат у Звіті про прибутки і збитки (таблиця 5).

Табличя 5

Аналіз показників Звіту про прибутки і збитки орендаря

\begin{tabular}{|c|c|c|c|c|c|c|}
\hline Стаття & $\mathbf{2 0 1 9}$ & $\mathbf{2 0 2 0}$ & $\mathbf{2 0 2 1}$ & $\mathbf{2 0 2 2}$ & $\mathbf{2 0 2 3}$ & Разом \\
\hline Початкові прямі витрати & 15000 & & & & & $\mathbf{1 5 0 0 0}$ \\
\hline Витрати на відсотки & - & 10395 & 8020 & 5500 & 2830 & $\mathbf{2 6 7 4 5}$ \\
\hline Витрати на амортизацію & 47651 & 47651 & 47651 & 47651 & 47651 & $\mathbf{2 3 8} 255$ \\
\hline Разом & $\mathbf{6 2 ~ 6 5 1}$ & $\mathbf{5 8 ~ 0 4 6}$ & $\mathbf{5 5 6 7 1}$ & $\mathbf{5 3 1 5 1}$ & $\mathbf{5 0 4 8 1}$ & $\mathbf{2 6 5 0 0 0}$ \\
\hline \multicolumn{7}{|c|}{ Чинна угода про операиійну оренду } \\
\hline Початкові прямі витрати & 15000 & & & & & $\mathbf{1 5 0 0 0}$ \\
\hline Витрати на оренду & 50000 & 50000 & 50000 & 50000 & 50000 & $\mathbf{2 5 0 0 0 0}$ \\
\hline Разом & $\mathbf{6 5 0 0 0}$ & $\mathbf{5 0 ~ 0 0 0}$ & $\mathbf{5 0 0 0 0}$ & $\mathbf{5 0 0 0 0}$ & $\mathbf{5 0 0 0 0}$ & $\mathbf{2 6 5 0 0 0}$ \\
\hline
\end{tabular}

Різна подальша оцінка після первісного визнання Права користування активу (амортизація зазвичай визнається рівномірно) і Зобов'язань з оренди (відсоток розраховують із використанням методу постійної норми прибутковості) призводить до самого, ймовірно, значного впливу застосування нового Стандарту MCФЗ (IFRS) 16 «Оренда» на чистий прибуток орендаря, оскільки загальні витрати будуть вищі на початку періоду оренди (у зв'язку з більш високими відсотковими витратами на початку періоду оренди), в той час як відповідно до чинного МСБО (IAS) 17 «Оренда» витрати на операційну оренду, зазвичай, визнаються рівномірно протягом терміну оренди. 
Висновки. Отже, роведений аналіз основних положень МСФЗ (IFRS) 16 «Оренда» дає змогу визначити основні підходи до відображення в обліку орендних операцій в орендаря:

1. Усунено відмінність між поняттями фінансової й операційної оренди. Натомість стандарт пропонує єдину модель обліку для орендаря.

2. Новизною $є$ вимога до орендарів відображати укладання угоди операційної оренди у звіті про фінансовий стан, а саме: представляти актив у формі Права користування та відповідне Зобов'язання 3 оренди.

3. Як орендодавці, так і орендарі можуть прийняти рішення про незастосування моделі обліку оренди щодо договорів оренди з максимальним строком оренди до 12 місяців відповідно до порядку, аналогічним обліку нині чинної операційної оренди.

4. Для того, щоб оцінити потенційний вплив запропонованих у стандарті підходів, підприємству потрібно буде провести додатковий аналіз і інтерпретувати вимоги стандарту з урахуванням власних фактів, обставин і окремих операцій.

\section{Література:}

1. Гришунина Е., Плюснин А. Проект стандарта «Лизинг». МСФО на практике. 2013. № 8. URL: http:// msfo-practice.ru/article.aspx?aid=316776 (дата звернення: 25.04.2018).

2. Небильцова О. В. Проблеми та перспективи запровадження нового міжнародного стандарту з обліку оренди. Ефективна економіка. 2015. № 12. URL: http://www.economy.nayka.com.ua/?op=1\&z=4630 (дата звернення: 25.04.2018).

3. Хома С., Василенко Н. Облік оренди в контексті проекту міжнародного стандарту «Оренда». Бухгалтерський облік і аудит. 2014. № 4. С. 19-26.

4. Корвяков В. Оприлюднено новий стандарт - МСФЗ 16 «Оренда». Вісник МСФЗ Світовий досвід. Українська практика. URL: http://msfz.ligazakon.ua/ua/magazine_article/FZ000875 (дата звернення: 05.05.2018). 